\title{
УПРАВЛІННЯ ЯКІСТЮ ЯК ФАКТОР ПІДВИЩЕННЯ ЕФЕКТИВНОСТІ ТУРИСТИЧНИХ ТА РЕСТОРАННИХ ПОСЛУГ В СФЕРІ МІЖНАРОДНОГО ТУРИСТИЧНОГО БІЗНЕСУ
}

\author{
QUALITY MANAGEMENT AS A FACTOR \\ OF IMPROVING THE EFFICIENCY OF TOURIST \\ AND RESTAURANT SERVICES IN THE FIELD \\ OF INTERNATIONAL TOURIST BUSINESS
}

\author{
Чуєва Інна Олександрівна \\ кандидат наук фрізичного виховання і спорту, доцент, \\ Запорізький національний університет \\ ORCID: https://orcid.org/0000-0001-8697-7602 \\ Сидорук Анна Вікторівна \\ кандидат педагогічних наук, доцент, \\ Запорізький національний університет \\ ORCID: https://orcid.org/0000-0002-8466-6912 \\ Кравченко Дар'я Михайлівна \\ адміністратор ресторану «Monica Belucci», м. Запоріжжя \\ ORCID: https://orcid.org/0000-0003-0797-3588

\section{Chuieva Inna, Sydoruk Anna} \\ Zaporizhzhya National University \\ Kravchenko Dariya \\ Administrator of the Restaurant "Monica Belucci", Zaporizhzhya
}

\begin{abstract}
У статті розглядаються особливості категоріального апарату туристичних та ресторанних послуг. Проаналізовані основні поняття, на яких базується система управління якістю в туризмі та ресторанному бізнесі. На сьогоднішній день структура гостинності склалася таким чином, що не повністю відповідає потребам економіки, з перевагою в бік позакатегорійних і високо розрядних туристичних та ресторанних підприємств, тоді як найбільш затребуваними $€$ середнього рівня. Наразі не тільки окремі організації, а й більшість територіальних туристично-рекреаційних комплексів не мають чіткого позиціонування на ринку, існує розрив між рівнем якості та іншими споживчими характеристиками пропонованими споживачам туристичними та ресторанними послугами. Процеси, що відбуваються в туристичній ссрері, обумовлюють необхідність пошуку і впровадження нових підходів, фрорм і методів ефективного управління складовими споживчої привабливості туристичних та ресторанних послуг в умовах обмежених ресурсів, фрормування систем управління фракторами - домінантами, серед яких найбільш вагоме значення при виборі того чи іншого виробництва має саме якість послуг, що надаються. Необхідно використовувати позитивний міжнародний досвід застосування стандартів якості серії ISO 9000, реалізації концепції загального управління якістю.

Ключові слова: туристичні послуги, ресторанні послуги, управління якістю, туристична ссрера, ссрера гостинності, міжнародний туристичний бізнес.
\end{abstract}

В статье рассмотрены особенности категориального аппарата туристских и ресторанных услуг. Проанализированы основные понятия, на которых базируется система управления качеством в туризме и ресторанном бизнесе. На сегодняшний день структура гостеприимства сложилась таким образом, что не полностью соответствует потребностям экономики, с преобладанием в сторону внекатегорийных и высоко разрядных туристических и ресторанных предприятий, тогда как наиболее востребованы среднего уровня. Сейчас не только отдельные организации, но и большинство территориальных туристско-рекреационных комплексов не имеют четкого позиционирования на рынке, существует разрыв между уровнем качества и другими потребительски- 
ми характеристиками предлагаемыми потребителям туристическими и ресторанными услугами. Процессы, происходящие в туристической сфере, обусловливают необходимость поиска и внедрения новых подходов, форм и методов эффрективного управления составляющими потребительской привлекательности туристических и ресторанных услуг в условиях ограниченных ресурсов, формирование систем управления факторами доминантами, среди которых наиболее важное значение при выборе того или иного производства имеет именно качество предоставляемых услуг. Необходимо использовать положительный международный опыт применения стандартов качества серии ISO 9000, реализации концепции всеобщего управления качеством.

Ключевые слова: туристические услуги, ресторанные услуги, управление качеством, туристическая сорера, сорера гостеприимства, международный туристический бизнес.

The article considers the features of the categorical apparatus of tourist and restaurant services. The basic concepts are analyzed, on which the quality management system in tourism is based. Nowadays, the structure of hospitality has developed in such a way that it does not fully meet the needs of the economy, with an advantage towards out-of-category and high-level tourism and restaurant enterprises, while the most popular are medium-level. Currently, not only individual organizations, but also most of the territorial tourist and recreational complexes do not have a clear positioning in the market, there is a gap between the level of quality and other consumer characteristics of tourist and restaurant services offered to consumers. The processes taking place in the tourism sector necessitate the search for and implementation of new approaches, forms and methods of effective management of the components of consumer attractiveness of tourist and restaurant services in conditions of limited resources, the formation of management systems. production has the quality of services provided. It is necessary to use the positive international experience of application of quality standards of the ISO 9000 series, realization of the concept of the general quality management. The prevailing concept of quality management of tourist and restaurant services is mainly focused on the impact on the controlled quality parameters of technical and functional nature, including restaurant interiors, the volume of basic and additional services offered at the level of individual production. Comprehensive quality management of tourist and restaurant services is allowed as possible and necessary, but at the same time is not implemented in the proper amount, limited to aspects of control, accounting. However, the steps taken to address this problem, related to the promotion of quality, the formation of a culture of production and consumption of quality products and services, are not sufficient, as they do not have a real basis for effective consolidation. The reasons for this lie outside the following of the subjects of supply and demand, the structures of management of changes in market conditions and their existence in different information environments, the actual separation from each other.

Keywords: tourist services, restaurant services, quality management, tourist sphere, hospitality sphere, international tourist business.

Постановка проблеми. Діяльність туристичних підприємств та закладів громадського харчування значно впливає на якість і культуру життя населення, адже, надаючи, наприклад ресторанні послуги, підприємства задовольняють не тільки фрізіологічні, але й соціальні, духовні потреби людини - в спілкуванні, визнанні, новизні, гармонії тощо. Від ступеня задоволеності таких запитів споживачів залежить відвідуваність, a, отже, - успіх і стабільність розвитку підприємства.

У зв'язку з високою конкуренцією на туристичному ринку будь-яка організація повинна постійно розглядати варіанти підвищення якості послуг, зокрема, в ресторанному бізнесі. Категорію якості можна розглядати як властивості або характерні особливості послуг, тобто чим більше властивостей - тим вище рівень якості. Застосовуючи десрініцію «якість» в даному контексті до меню ресторану, слід визначити ступінь якості, в першу чергу, величиною пропонованого асортименту страв і місткістю залу. 3 технічної точки зору якість розглядається як результат взаємодії з організацією; у випадку з підприємством громадського харчування результатом $€$ їжа. 3 фрункціональної точки зору якість - це рівень обслуговування, і в розрізі даної теми таких можна вважати професіоналізм офріціантів, створену атмосферу в ресторані. В цілому, під наданням ресторанних чи туристичних послуг (обслуговуванням) мають на увазі систему трудових операцій, доцільних дій, різних зусиль, які реалізуються виробниками сервісного продукту для споживачів з метою задоволення їх запитів і надання їм передбачених благ і зручностей.

Аналіз останніх досліджень і публікацій. Питанням управління якості туристичних та ресторанних послуг на арені міжнародного туристичного бізнесу присвячені наукові доробки вітчизняних та закордонних вчених: Р.В. Апілата, А.В. Вакуленка, А.В. Кравецького, І.І. Калашника тощо [1-4].

Виділення невирішених раніше частин загальної проблеми. Значущим компонентом систем управління якістю послуг є стандартизація, що представляє собою нормотворчу діяльність, вишукувати максимально раціональні норми 3 наступним їх закріпленням в нормативних документах рівня стандартів, інструкцій, методик і вимог до розробки нових ресторанних чи туристичних послуг; тобто під стандартизацією мається на увазі сукупність засобів, які встановлюють відповідність стандартам. У сучасних реаліях стандартизація $€$ одним з ключових ланок механізму управління якістю продукції (робіт, послуг тощо). 
Формулювання цілей статті (постановка завдання). Метою даної статті $€$ дослідження управління якості як фрактору підвищення есрективності туристичних та ресторанних послуг на арені міжнародного туристичного бізнесу.

Виклад основного матеріалу дослідження. Відповідно до визначення Міжнародної організації по стандартизації (ICO), стандартизація визначається як встановлення і застосування норм і правил для впорядкування діяльності в конкретних ссрерах для користі і за участю всіх зацікавлених сторін, в тому числі з метою загальної оптимальної економії в процесі дотримання функціональних умов і норм техніки безпеки [2].

На базі аналізу зовнішнього і внутрішнього середовища організації виробляється система управління якістю обслуговування, де ключовим елементом виступають стандарти обслуговування. Під стандартами обслуговування розуміються критерії, потрібні для забезпечення достатньої есрективності системи менеджменту якості. Стандарти обслуговування представляють собою комплекс процедур і щоденних операцій, які виконуються персоналом і сприяють максимально можливому задоволенню клієнтів.

Головні принципи розробки стандартів надання ресторанних чи туристичних послуг повинні відповідати наступним вимогам:

- повинні бути точними, вимірюваними, ясними;

- створюються виходячи з думки і поглядів реальної клієнтури;

- зобов'язані бути досяжними, здійсненними для співробітників;

- бути гнучкими в різних ринках збуту;

- повинні передбачати можливі витрати;

- формулюються 3 умовою того, що вони розуміються і приймаються всім персоналом ресторану чи туристичної компанії;

- публічно анонсуються;

- фрормуються для визначення рівня розвитку організації, аналізу рівня сервісу і ступеня задоволеності споживачів;

- можуть змінюватися в майбутньому, оскільки мають властивість застарівати [3].

Безпосередньо в процесі зміни слід умовно виділяти три групи стандартів, які варто відстежувати:

1) чистота і санітарія;

2) якість страв;

3) обслуговування.

Всі співробітники ресторану з точки зору кваліфрікаційних вимог повинні бути розділені на три великі групи:
1) керівний склад, (директор, менеджери, адміністратори);

2) персонал, який безпосередньо працює 3 клієнтами (офіціанти, бармени);

3) господарські структури (техніки, складські робітники тощо).

Рівень компетенціїперсоналуданихгруп має серйозне значення для здійснення управління якістю. Менеджмент ресторану зобов'язаний стежити за тим, щоб персонал мав необхідну кваліфікацію, знання і навички для виконання свого фрункціоналу з максимальною віддачею. Загальні вимоги до персоналу в такі:

- ввічливість, дружелюбність, ентузіазм, співпраця 3 колегами, взаємодія з клієнтами;

- гнучкість, пристосовність;

- відповідальність, ініціативність;

- акуратність, охайність;

- дисциплінованість, старанність;

- знання своїх обов'язків, якісність виконання роботи, спостережливість;

- робота при підвищеному навантаженні, в стресовій обстановці;

- наполегливість, цілеспрямованість;

- усвідомлення витратності;

- знання іноземних мов [5].

Якість послуги можна визначати ступенем відповідності комплексу їі характерних рис і властивостей запитам споживача при обліку ціни, яку він готовий сплатити за надану послугу [3].

Обслуговування клієнта в ресторані можна розділити на кілька етапів.

Перший етап - передпродажний, який має на увазі інфрормаційне обслуговування, демонстрацію товарів, дегустацію.

Другий - основний етап - обслуговування клієнта. Надання послуг офріціанта відбувається в обмеженій контактній зоні. Основні вимоги до співробітника сервісу при цьому зводяться до наступного: не доставляти клієнту утруднень без гострої необхідності, запобігати виникненню у дискомфортного відчуття, бути чемним. Працівник контактної зони зобов'язаний при будь-якій відповідній реакції клієнта зберігати, з одного боку, ввічливість і чуйність, з іншого - спокій і делікатність [1].

Останній етап - постпродажне обслуговування, орієнтоване на перетворення відвідувача в постійного клієнта. В даному випадку, це, наприклад, подарункові сертисрікати, знижки на майбутні придбання, vіркарти тощо.

Високий рівень якості обслуговування клієнтів виступає не тільки конкурентною перевагою підприємства, але і в значній мірі, впливає на формування лояльного ставлення клієнтів, зміщує акцент з питання вартості на питання задо- 
волення обслуговуванням. Нині, під якісним обслуговуванням крім зручного місця розташування, великого асортименту, провідної позиції в товарній групі, а іноді і конкурентоспроможних цін, розуміються і такі фрактори, як адекватність співробітників підприємства, знання продукту, причетність персоналу до процесу вибору товару, їх зацікавленість та ініціативність [3].

Для управління якістю послуг застосовують систему економічних, координаційних, психолого-соціальних, директивних, виробничих методів. Всі вони, в більшій чи меншій мірі використовуються в практиці підприємств, що фуункціонують в області ресторанного бізнесу. Що стосується власне методів, то найбільш значущими з них $є$ :

- вивчення основ в роботі з клієнтами, з підприємствами-конкурентами з метою виявлення сильних і слабких аспектів власної діяльності;

- систематизація та аналіз бази даних думок і оцінок споживачів про підприємстві, його недоліки та позитивних сторін;

- статистичні методи в оцінці якісних результатів компанії громадського харчування [6].

Як правило, для подальшого позитивного впливу на підвищення якості послуг, що надаються досить вивчення масиву негативних факторів і претензій, які висловили споживачі.

Найбільш чутливим і найважливішим фрактором якості обслуговування, а також рушійною силою підприємств громадського харчування $€$ його персонал. Потреби відвідувачів підприємств громадського харчування все більше набувають індивідуальний характер, що вимагає від персоналу не тільки профресіоналізму, а й високої особистої культури, зацікавленості співробітників в якості обслуговування гостей. Якість і культура роботи співробітників в свою чергу залежать не тільки від виконання стандартів, правил обслуговування, але і від задоволеності співробітників своєю роботою, відносинами в колективі, визнанням керівниками результатів їх праці. У цьому світлі співробітник підприємства виступає в якості внутрішнього споживача підприємства, від задоволеності якого буде залежати задоволеність зовнішнього споживача - клієнта підприємства [1].

Висновки. Отже, управління якістю як фрактор підвищення ефрективності туристичних та ресторанних послуг - це менеджмент четвертого покоління, який в справжніх реаліях стає провідним менеджментом підприємств і установ організацій та фрірм різних фрорм власності. Найвища конкуренція в будь-якій сфрері бізнесу, в тому числі - ресторанної, змушує підприємства ретельно стежити за якістю послуг. Важливим елементом при управлінні якістю є стандартизація. Найбільш відчутним чинником якості обслуговування виступає робота з персоналом.

\section{СПИСОК ВИКОРИСТАНИХ ДЖЕРЕЛ:}

1. Апілат Р.В. Модель механізму управління якістю послуг у підприємствах туризму. Економічна стратегія і перспективи розвитку сфрери торгівлі та послуг. Харків : ХДУХТ, 2014. Вип. 1(11). С. 677-681.

2. Вакуленко А.В. Управління якістю : Навчально-методичний посібник для самостійного вивчення дисципліни. Київ : КНЕУ, 2013. 167 с.

3. Кравецький А.В., Бабчинська О.І. Менеджмент якості: проблеми та перспективи запровадження на вітчизняних підприємствах. URL: http://www.rusnauka.com/15_APSN_2010/Economics/67675.doc.htm

4. Калашник I.І. Контроль та управління якістю продукції на промислових підприємствах. Держава та регіони. Серія : Економіка і підприємництво. 2013. № 1. С. 53-58.

5. Стандарти якості для послуг з добору персоналу. URL: http://www.arka.com.ua/standards

6. ISO 9001:2008 Quality management systems - Requirements. URL: www.iso.org/iso/catalogue_detail? csnumber $=46486$

\section{REFERENCES:}

1. Apilat R.V. (2014) Model mekhanizmu upravlinnia yakistiu posluh u pidpryiemstvakh turyzmu. Ekonomichna stratehiia i perspektyvy rozvytku sfery torhivli ta posluh. Kharkiv: KhDUKhT, vol. 1(11), pp. 677-681.

2. Vakulenko A.V. (2013) Upravlinnia yakistiu: Navchalno-metodychnyi posibnyk dlia samostiinoho vyvchennia dystsypliny. Kyiv: KNEU, 167 p.

3. Kravetskyi A.V., Babchynska O.I. Menedzhment yakosti: problemy ta perspektyvy zaprovadzhennia na vitchyznianykh pidpryiemstvakh. Available at: http://www.rusnauka.com/15_APSN_2010/Economics/67675.doc.htm

4. Kalashnik I.I. (2013) Kontrol ta upravlinnia yakistiu produktsii na promyslovykh pidpryiemstvakh. Derzhava ta rehiony. Seriia: Ekonomika i pidpryiemnytstvo, no. 1, pp. 53-58.

5. Standarty yakosti dlia posluh z doboru personalu. Available at: http://www.arka.com.ua/standards

6. ISO 9001:2008 Quality management systems - Requirements. Available at: www.iso.org/iso/catalogue_ detail? csnumber $=46486$ 